\title{
PENGARUH OPENNESS TERHADAP AKTIVITAS FISIK MELALUI MEDIASI OTONOMI PADA DEWASA MUDA
}

\author{
Welan Mauli Angguna', Fivi Nurwianti², \\ ${ }^{1}$ Program Studi Psikologi, Universitas Indonesia, Depok \\ Email:welan.mauli61@ui.ac.id \\ ${ }^{2}$ Program Studi Psikologi, Universitas Indonesia, Depok \\ Email: fivinurwianti2016@gmail.com
}

\begin{abstract}
Indonesia is considered a country with considerably low physical activity, therefore, it is necessary to promote physical activity to prevent degenerative diseases and death at a young age. Personality trait is considered a strong psychological factor in identifying physical activity. Recent research shows that the openness personality trait significantly influences physical activity. Openness is described as being open to accept various ideas and experiences, and is able to appreciate its diversity. Openness with the characteristics of being open allows individuals to receive information about the importance of physical activity, so that they are more active in carrying out activities. However, the effect of openness is inconsistent with some findings, so another variable is considered, such as autonomy which mediates this relationship. Autonomy is the degree to which individuals voluntarily choose to perform certain behaviors, when motivation to carry out behavior originates from within, this makes individuals maintain a behavior better. Autonomy is considered capable of increasing physical activity, because internal motivation (autonomy) is needed to maintain consistency in physical activity. This study aims to examine the mechanism of the relation between openness and physical activity through autonomy mediation. The study was conducted through selfreporting in 59 young adult men and 144 young adult women aged 20-40 years. Through analysis of the mediation process (Hayes), it is found that openness significantly affected physical activity when mediated by autonomy.
\end{abstract}

Keywords: openness, autonomy, physical activity, young adults

\begin{abstract}
ABSTRAK
Indonesia dianggap sebagai negara dengan aktivitas fisik masyarakat yang cukup rendah, sehingga diperlukan promosi aktivitas fisik untuk pencegahan terhadap penyakit degeneratif dan kematian di usia muda. Trait kepribadian dianggap sebagai faktor psikologis kuat dalam identifikasi aktivitas fisik. Penelitian terbaru menunjukkan bahwa trait kepribadian openness signifikan memengaruhi aktivitas fisik. Openness digambarkan sebagai keterbukaan untuk menerima berbagai ide dan pengalaman, serta mampu menghargai keragamannya. Openness dengan karakteristik keterbukaan memungkinkan individu menerima informasi mengenai pentingnya aktivitas fisik, sehingga mereka lebih aktif melakukan aktivitas. Namun, pengaruh openness tidak konsisten pada beberapa temuan yang lain, sehingga dipertimbangkan adanya variavel lain, seperti otonomi yang memediasi hubungan ini. Otonomi merupakan derajat seberapa individu secara sukarela mau melakukan perilaku tertentu, ketika motivasi melakukan perilaku berasal dari dalam diri, hal ini membuat individu lebih mampu mempertahankan suatu perilaku. Otonomi dianggap mampu meningkatkan aktivitas fisik, karena motivasi internal (otonomi) diperlukan untuk menjaga konsistensi melakukan aktivitas fisik. Penelitian ini bertujuan untuk menguji mekanisme hubungan openness dengan aktivitas fisik melalui mediasi otonomi. Penelitian dilakukan melalui lapor diri pada 59 laki-laki dan 144 perempuan dewasa muda berusia 20 - 40 tahun. Melalui analisis process mediasi (Hayes), ditemukan bahwa openness memengaruhi aktivitas fisik secara signifikan ketika dimediasi oleh otonomi.
\end{abstract}

Kata Kunci: openness, otonomi, aktivitas fisik, dewasa muda.

\section{PENDAHULUAN}

\section{Latar belakang}

Penyakit tidak menular atau penyakit degeneratif akhir-akhir ini menarik perhatian sebagai faktor risiko penyebab kematian di dunia (WHO, 2017). Hal ini sejalan dengan temuan Badan Penelitian dan Pengembangan Kementrian Kesehatan Republik Indonesia (2014) bahwa tujuh dari 10 penyebab kematian utama di Indonesia adalah penyakit degeneratif yaitu stroke, jantung iskemik dan diabetes (cnnindonesia, 2017; Kemenkes RI, 2017). Seiring dengan berkembangnya teknologi dan berbagai faktor risiko semakin berkembang pula jumlah anak muda yang menjalani gaya hidup 
tidak sehat dan kekurangan aktivitas fisik sehingga semakin rentan terhadap penyakit degeneratif (Macovei, Tufan, \& Vulpe, 2014). Pada tahun 2008 diperkirakan 17,3 juta kematian disebabkan penyakit degeneratif dan lebih 3 juta kematian tersebut terjadi pada usia di bawah 60 tahun (antaranews, 2017).

Menurut WHO (2017), kekurangan aktivitas fisik merupakan faktor penting penyebab penyakit degeneratif sehingga dianggap sebagai salah satu faktor risiko yang membawa kematian di dunia, karena sesungguhnya penyakit ini bisa dicegah dengan menjalani gaya hidup sehat, seperti mengurangi rokok, melakukan aktivitas fisik, dan tidak mengonsumsi alkohol (Kemenkes, 2017). Jika ditinjau dari faktor risiko penyebab penyakit degeneratif, tidak heran jika penyakit ini menjadi penyebab utama kematian di Indonesia, khususnya terkait kekurangan aktivitas fisik. Berdasarkan survei yang dilakukan Tim Althoff dari Stanford University diketahui bahwa Indonesia termasuk negara yang minim aktivitas fisik khususnya dalam berjalan kaki, selain itu penduduk Indonesia yang mengalami obesitas berusia di atas 18 tahun juga mengalami peningkatan dari $15,4 \%$ pada tahun 2013 menjadi 20,5\% di tahun 2016 (BBC, 2017).

Aktivitas fisik menurut WHO (2017) adalah pergerakan tubuh oleh kerangka otot yang membutuhkan pengeluaran energi, termasuk aktivitas yang terjadi ketika bekerja, bermain, mengerjakan pekerjaan rumah tangga, dan berekreasi. Aktivitas fisik digolongkan atas aktivitas ringan, sedang dan berat, pengelompokan ini berbeda tergantung pada seberapa besar energi yang diketahui dari perubahan pernapasan dan ketahanan dalam melakukan aktivitas tersebut (Nurmalia, dalam Juliana, 2015). Pada orang dewasa (usia 18-64 tahun) perlu melakukan paling sedikit aktivitas fisik moderat selama 150 menit/minggu, dan aktivitas fisik kuat selama 75 menit/minggu demi menjaga kesehatan tubuh (WHO, 2017). Aktivitas fisik dan olahraga selain membuat tubuh menjadi lebih indah juga berasosiasi dengan kesehatan (fisik maupun mental), mengurangi risiko kematian, dan kualitas hidup yang lebih baik (Butkovic, Hlupic, \& Bratko, 2017; Stephan, Sutin, \& Terracciano, 2014; Macovei et al., 2014).

Faktor yang membuat seseorang menjadi lebih aktif atau lebih tidak aktif beraktivitas dipengaruhi oleh variabel yang terkait dalam kategori demografis, personal, sosial dan lingkungan (Rhodes \& Nigg, 2011). Jenis kelamin adalah satu di antara variabel demografis yang cukup kuat dalam membedakan tingkat aktivitas fisik, dimana laki-laki biasanya lebih aktif daripada perempuan (Kern, Reynold, \& Friedman, 2010; Asci et al., 2015; Butkovic et al., 2017, Coen, Rosenberg, \& Davidson, 2018).

Studi terbaru mengenai promosi kesehatan dan psikologi olahraga memfokuskan pada identifikasi variabel psikologis seperti kepribadian, presentasi diri, dan motivasi yang memengaruhi tingkah laku berolahraga (Asci, Lindwall, Altintas, \& Gursel, 2015). Terdapat berbagai alasan yang membuat manusia memutuskan untuk aktif melakukan aktivitas fisik, dan kepribadian adalah variabel yang pasti terkait dengan perilaku, karena kepribadian adalah pola trait yang relatif menetap dan karakteristik khusus yang memengaruhi tingkah laku individu menjadi khas dan konsisten, sehingga kepribadian sangat mampu untuk memengaruhi tingkah laku aktif beraktivitas (Feist \& Feist, 2013; Butkovic et al., 2017).

Pola hubungan trait kepribadian dengan aktivitas fisik bisa berbeda tergantung karakteristik partisipan dan analisis yang digunakan. Berbagai penelitian menunjukkan bahwa trait kepribadian extraversion dan conscientiousness yang tinggi disertai dengan neuroticism yang rendah berkaitan dengan tingginya aktivitas fisik (Rhodes \& Smith, 2006; Lochbaum, Rhodes, Stevenson, Surles, 
Stevens, \& Wang., 2010; Kern et al., 2010; Wilson \& Dishman, 2015), ketiga trait tersebut sudah konsisten memengaruhi aktivitas fisik secara langsung.

Lebih lanjut melalui studi meta-analisis pada berbagai studi oleh Wilson dan Dishman (2015) menemukan bahwa selain extraversion, conscientiousness, dan neuroticism, trait openness diketahui juga kuat memengaruhi aktivitas fisik, namun tidak menemukan hubungan antara agreeableness dan aktivitas fisik. Melalui temuan di atas, dapat diketahui bahwa terdapar temuan yang tidak konsisten mengenai pengaruh openness terhadap aktivitas fisik. Hal ini memungkinkan adanya peran variabel lain yang menjembatani hubungan tersebut.

Otonomi menurut Ryan dan Deci (2017) merupakan derajat seberapa individu secara sukarela tanpa paksaan terlibat dengan tingkah laku tertentu, karena sesuai dengan kemauan sendiri (motivasi intrinsik), atau karena dorongan eksternal (motivasi ekstrinsik) yang telah diregulasi sesuai dengan kebutuhan sehingga menjadi kemauan sendiri. Perilaku aktif melakukan aktivitas fisik dipengaruhi oleh otonomi diri, karena motivasi internal (otonomi) diperlukan untuk menjaga konsistensi untuk tetap aktif melakukan aktivitas fisik (Ingledew \& Markland, 2008; Lewi \& Sutton, 2011; Teixeira, Caracca, Markland, Silva, \& Ryan, 2012; Bowman, 2015; Ramsey \& Hall, 2016).

Otonomi diri berkaitan erat dengan trait kepribadian openness. Individu dengan openness tinggi cenderung menerima ide dan kesempatan mendapatkan pengalaman baru, mereka secara sukarela mau mencoba hal baru, sehingga lebih mau dan sering terlibat dengan berbagai bentuk aktivitas fisik (Wilson \& Dishman, 2015). Selain terbuka dengan pemikiran maupun pengalaman baru, individu yang terbuka juga dengan senang hati mencari berbagai informasi baru (Feist \& Feist, 2013), hal ini memungkinkan mereka memiliki otonomi tinggi untuk aktif melakukan aktivitas fisik dalam upaya menjaga kesehatan sesuai pemahaman dari informasi yang mereka dapatkan. Otonomi dianggap potensial menjembatani hubungan openness dan aktivitas fisik, terkait dengan tingginya serapan informasi mengenai pentingnya aktvitas fisik untuk menjaga kesehatan pada individu yang terbuka, membuat individu memiliki otonomi untuk terdorong aktif melakukan aktivitas fisik, sehingga dorongan ini diwujudkan dengan melakukan aktivitas fisik yang tinggi.

\section{Rumusan Masalah}

Apakah terdapat pengaruh yang signifikan antara trait openness terhadap aktivitas fisik melalui mediasi otonomi pada dewasa muda?

\section{METODE PENELITIAN}

\section{Partisipan}

Partisipan penelitian ini berjumlah 203 orang Indonesia (59 laki-laki; 144 perempuan) yang berusia 20 - 40 tahun. Partisipan penelitian ini sebagian besar memiliki indeks massa tubuh yang sehat (healthy weight), berpendidikan S1 $(65,7 \%)$, berada pada usia 24 tahun $(20,7 \%)$, dan rutin berolahraga $(54,2 \%)$. Partisipan terlibat dalam penelitian ini dengan mengisi kuesioner online menggunakan google form yang dibagikan melalui media sosial seperti: whatsapp, line, instagram, dan facebook. Peneliti menyebarkan pengumuman berupa ajakan bagi laki-laki dan perempuan yang berusia 20 hingga 40 tahun untuk terlibat pada penelitian mengenai gaya-hidup dewasa muda, 
calon partisipan diminta mengisi kuesioner online dengan meng-klik link yang tertera pada pengumuman tersebut. Pada pengumuman tersebut juga diinformasikan bahwa 20 partisipan yang terpilih melalui undian berhak mendapatkan pulsa/saldo go-pay sebesar Rp.20.000.

\section{Alat Ukur}

International Physical Activity Questionnaire (IPAQ)- short form

IPAQ terdiri atas 7 aitem yang mengukur laporan aktivitas fisik individu, terdiri atas pertanyaan mengenai lama waktu berjalan, melakukan aktivitas fisik sedang, aktivitas fisik berat, dan lama waktu duduk dalam seminggu. Alat ukur ini memiliki nilai reliabilitas nilai median validitas kriteria sebesar 0,3 dan nilai median reliabilitas sebesar 0,8 yang diujikan pada berbagai negara berbeda (Craig, 2003).

The Big Five Personality Inventory (BFI)

BFI adalah instrumen untuk menilai trait kepribadian individu. Inventori ini mengukur trait kepribadian individu berdasarkan lima dimensi yang multidimensional: extraversion, conscientiousness, agreeableness, neuroticism, dan openness. Alat ukur ini adalah multidimensional, dimana setiap dimensi masing-masing memiliki satu skor. Inventori ini adalah hasil adaptasi The Big Five inventory versi 44 aitem ( John \& Sirastava, 1999) yang diadaptasi oleh Ramdhani (2012) menjadi BFI yang terdiri atas 28 aitem dengan penilaian 5 skala (1= sangat tidak setuju) hingga ( $5=$ sangat setuju). Inventori ini memiliki nilai reliabilitas $0,70-0,79$ dan validitas $0,4-0,8$ pada masing-masing dimensi.

\section{The Behavioral Regulation in Exercise Questionnaire-2 (BREQ-2)}

BREQ-2 terdiri atas 19 aitem dalam 5 skala (0-4) yang digunakan untuk mengukur determinasi diri individu untuk bergerak. Alat ukur ini memiliki 5 dimensi meliputi: amotivasi, regulasi eksternal, introjected regulation, identified regulation, dan regulasi internal. Skor pada alat ukur menunjukkan semakin tinggi skor maka semakin besar otonomi, skor ini didaptkan dari nilai Relative Autonomi Index (RAI). Skor positif mengindikasikan semakin besar otonomi, dan skor negatif mengindikasikan regulasi yang terkontrol. Markland dan Tobin (2004) menunjukkan bahwa BREQ-2 berdasarkan confirmatory factor analysis model ini fit dengan data (SatorraBentler Scaled Chi Sq $=136.49, \mathrm{df}=125, \mathrm{p}=.23$; CFI = .95; RMSEA = .02, 90\% CI = .00 - .04; SRMR = .05), dan memiliki nilai reliabilitas berdasarkan cronbach alpha $(0,73-0,86)$.

\section{Analisis Statistik}

Dalam rangka menguji pengaruh otonomi dalam memediasi hubungan openness dan aktivitas fisik, penelitin ini menggunakan analisis statistik mediasi sederhana menggunakan Macro PROCESS Hayes pada SPSS 22 for Windows. Analisis mediasi sederhana (Hayes, 2013) merupakan metode statistik untuk menjelaskan mekanisme jalur hubungan, melalui model yang terdiri dari variabel sebab $(\mathrm{X})$ yang berhubungan dengan satu variabel akibat $(\mathrm{Y})$ melalui satu variabel perantara atau mediator (M).

\section{HASIL DAN PEMBAHASAN}

Gambaran variabel penelitian berdasarkan 203 responden, 51,2\% responden diketahui memiliki aktivitas fisik menengah ke atas dengan nilai median 2.853 MET, 49,8\% responden memiliki otonomi untuk beraktivitas fisik yang tinggi $(\mathrm{M}=41,2 ; \mathrm{SD}=8,7)$. Trait conscientiousness memiliki nilai rata-rata tertinggi $(\mathrm{M}=23,6 ; \mathrm{SD}=3,8)$, diikutin trait openness $(\mathrm{M}=22,9 ; \mathrm{SD}=3,4)$, dan extraversion memiliki skor rata-rata terendah $((\mathrm{M}=19,1 ; \mathrm{SD}=3,3)$. 
Trait kepribadian openness secara bersamaan dengan otonomi mampu memengaruhi aktivitas fisik secara signifikan. Kedua variabel ini memiliki kontribusi sebesar 5\% untuk memprediksi aktivitas fisik, dan sisanya dijelaskan oleh variabel lain. Jika dilihat lebih detail pada setiap variabel, variabel otonomi adalah prediktor yang signifikan memengaruhi aktivitas fisik $(p<0,05)$, sedangkan openness tidak signifikan memengaruhi aktivitas fisik secara langsung. Namun demikian, trait openness memiliki kontribusi sebesar $4 \%$ dalam memprediksi otonomi. Trait openness memengaruhi otonomi secara signifikan, dan otonomi juga secara signifikan memengaruhi aktivitas fisik. Namun, openness tidak signifikan memengaruhi aktivitas fisik secara langsung.

Tabel 1.

Model koefisien openness, otonomi, dan aktivitas fisik

\begin{tabular}{|c|c|c|c|c|c|c|c|c|}
\hline \multirow{3}{*}{ Prediktor } & \multicolumn{8}{|c|}{ Akibat } \\
\hline & \multicolumn{3}{|c|}{$M$ (Otonomi) } & \multicolumn{5}{|c|}{ Y (Aktivitas Fisik) } \\
\hline & & Coeff. & $S E$ & $P$ & & Coeff. & $S E$ & $P$ \\
\hline X (Openness) & $A$ & 0,49 & 0,17 & 0,01 & $c^{\prime}$ & 179,93 & 101,37 & 0,08 \\
\hline M (Otonomi) & & - & - & - & $B$ & 92,84 & 40,47 & 0,02 \\
\hline \multirow[t]{2}{*}{ Constant } & $i_{1}$ & 29,89 & 4,02 & 0,00 & $i_{2}$ & $-3730,61$ & 2603,61 & 0,15 \\
\hline & & $\begin{array}{l}\mathrm{R}^{2}=0,04 \\
F(1,201)\end{array}$ & $6, p<0,0$ & & & $\begin{array}{l}\mathrm{R}^{2}=0,05 \\
F(2,200)=\end{array}$ & $1, p<0,05$ & \\
\hline
\end{tabular}

Tidak terdapat pengaruh yang signifikan antara openness dan aktivitas fisik ketika mengontrol otonomi sebagai mediator. Otonomi memiliki pengaruh yang signifikan dalam memediasi hubungan antara openness dengan aktivitas fisik. Pengaruh langsung openness terhadap aktivitas fisik menjadi lebih kecil dan tidak signifikan setelah mengontrol otonomi $\left(c^{\prime}<c\right)$. Maka dari itu hipotesis alternative (Ha) diterima, dimana openness memengaruhi aktivitas fisik secara penuh melalui mediasi otonomi.

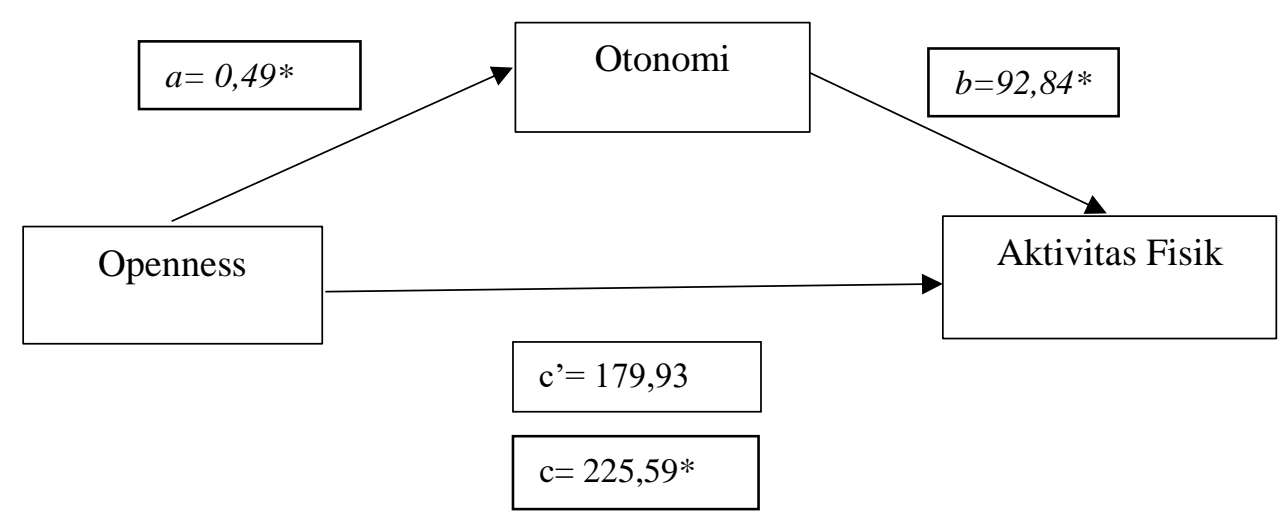

Model 1. Hubungan kausalitas openness, otonomi, dan aktivitas fisik 
Pengaruh tidak langsung menunjukkan bahwa perubahan pada satu unit trait openness diestimasi berdampak pada kenaikan aktivitas fisik sebesar 45,66 sebagai hasil dari otonomi yang lebih tinggi. Dampak tidak langsung ini secara statistik berbeda dari nol pada $95 \%$ bootstrap confidence inteval yang secara keseluruhan berada di atas nol (10,24 hingga 115,36). Berbeda dengan pengaruh langsung, ketika perubahan satu unit pada openness memengaruhi estimasi 179,92 aktivitas fisik pada kondisi otonomi yang diestimasikan sama. Namun pengaruh langsung ini tidak berbeda secara statistik dari nol, $t=1,78, p=0,08$ dengan $95 \%$ confidence interval yang melibatkan nol didalamnya $(-19,97$ hingga 379,82). Selanjutnya, pengaruh total openness terhadap aktivitas fisik yang diketahui dari penjumlahan pengaruh langsung dan tidak langsung, menunjukkan dampak statistik yang berbeda dari nol berdasarkan $95 \%$ bootstrap confidence inteval yang secara keseluruhan di atas nol (99,17 hingga 564,71). Maka dari itu, dapat disimpulkan bahwa openness secara signifikan memengaruhi aktivitas fisik seiring dengan meningkatnya otonomi.

\section{KESIMPULAN DAN SARAN}

Tujuan penelitian ini adalah untuk menguji pengaruh otonomi dalam memediasi hubungan openness dengan aktivitas fisik. Temuan pada penelitian ini mengindikasikan bahwa terdapat mediasi sempurna yang signifikan antara openness dengan aktivitas fisik melalui otonomi. Artinya, openness yang tinggi meningkatkan otonomi, sehingga berdampak pada aktivitas fisik yang lebih tinggi.

Pengaruh otonomi dalam memediasi hubungan openness dan aktivitas fisik terbukti, dimana terdapat mediasi sempurna bahwa trait kepribadian openness memang tidak memengaruhi aktivitas fisik secara langsung, melainkan hubungan tersebut menjadi signifikan ketika mengontrol otonomi sebagai mediator. Hasil penelitian ini menunjukkan bahwa openness berpengaruh terhadap aktivitas fisik ketika memiliki otonomi yang tinggi.

Temuan penelitian ini sejalan dengan Ingledew dan Markland (2008) yang membuktikan adanya hubungan trait openness dengan aktivitas fisik melalui mediasi motivasi untuk sehat dan identified regulation yang mengarah kepada semakin tinggi otonomi. Meningkatnya otonomi individu berdampak pada meningkatnya partisipasi individu untuk aktif berpartisipasi melakukan aktivitas fisik. Temuan tersebut menjadi pelengkap penjelasan mengapa semakin terbuka berdampak pada semakin tinggi otonomi untuk aktif melakukan aktivitas fisik. Diketahui bahwa individu yang terbuka cenderung mencari dan menyerap berbagai informasi baru dan beragam, informasi ini memunculkan pemahaman mengenai pentingnya kesehatan bagi mereka. Upaya memelihara kesehatan itu adalah dengan menjaga diri agar tetap aktif melakukan aktivitas fisik, hal ini diregulasi menjadi suatu kebutuhan sehingga individu memiliki determinasi diri untuk aktif bergerak. Motivasi yang berasal dari dalam diri inilah yang kemudian menjaga konsistensi individu untuk aktif melakukan aktivitas fisik dalam kehidupannya sehari-hari (Markland, Ingledew \& Sheppard, 2004; Ingledew \& Markland, 2008).

Perbedaan aktivitas fisik berdasarkan jenis kelamin tidak ditemukan pada studi ini $(t=0,78$, $p>0,44)$. Temuan ini berbeda dengan temuan sebelumnya,f bahwa aktivitas fisik berbeda antar jenis kelamin karena pengaruh norma- sosial yang tidak begitu mendukung perempuan untuk melakukan kegiatan fisik (Kern et al., 2010; Coen et al., 2018). Laki-laki dan perempuan tidak begitu berbeda dalam melakukan aktivitas fisik, hal ini mungkin berkaitan dengan konteks 
penelitian pada masyarakat moderen yang mulai mengalami penurunan gap peran antara laki-laki dan perempuan. Perempuan maupun laki-laki pada kelompok penelitian ini mungkin melakukan kegiatan sehari-hari yang tidak begitu berbeda, seperti membersihkan rumah, berolahraga, pergi bekerja, dan lain sebagainya. Aktivitas fisik ini menjadi tidak begitu berbeda, karena norma-sosial pada kelompok ini mungkin cenderung setara terhadap peran antar jenis kelamin.

Penelitian ini memiliki keterbatasan tertentu, dimulai dari komposisi responden, dimana jumlah responden perempuan jauh lebih banyak daripada responden laki-laki. Padahal menurut studi terdahulu, perbedaan jenis kelamin berhubungan erat dengan aktivitas fisik (Asci et al., 2015; Butkovic et al., 2017), sehingga lebih baik jika penelitian memiliki komposisi yang seimbang antar jenis kelamin. Jika komposisi tersebut seimbang, perbedaan pengaruh openness pada aktivitas fisik melalui mediasi otonomi bisa diuji antara laki-laki dan perempuan. Dalam rangka memastikan lebih jauh apakah keterbukaan individu dalam menerima informasi memang mendukung otonomi dan aktivitas fisik, sebaiknya dilakukan penelitian eksperimental pada dewasa muda dengan kecenderungan openness yang tinggi. Kedua kelompok diberi perlakuan yang berbeda, mengenai informasi betapa penting dan menyenangkannya aktif dalam beraktivitas fisik. Selanjutnya diuji bagaimana perbedaan pengaruh perlakukan terhadap aktivitas fisik pada dua kelompok yang berbeda.

Responden penelitian ini diambil dari kelompok yang umum, namun berdasarkan gambaran demografis diketahui bahwa sebagian besar responden rutin berolahraga. Pada penelitian selanjutnya, sebaiknya dilakukan penelitian pada populasi yang rutin berolahraga. Pengukuran aktivitas fisik sendiri mungkin bisa diuji menggunakan pengukuran yang lebih objektif seperti cek kebugaran, menggunakan alat seperti pedometer, akselerometer. Penelitian pada kelompok yang aktif berolahraga bisa berguna untuk mengetahui karakteristik dan hal yang motivasi mereka sehingga aktif melakukan aktivitas fisik, sehingga temuan tersebut bisa menjadi bahan untuk promosi melakukan aktivitas fisik yang lebih tepat sasaran.

\section{Ucapan Terima Kasih (Acknowledgement)}

Terimakasih kepada partisipan yang telah membantu penelitian ini dengan ikut berpartisipasi mengisi kuesioner penelitian secara online.

\section{REFERENSI}

Asci, F.H., Lindwallb, M., Altıntas, A., \& Gürsel, N.E. (2015). Gender differences in the relation of personality traits and self-presentation with physical activity. Science \& Sports, 30, 2330.

Biddle, S. \&Mutrie, N. (2008). Psychology of physical activity, Determinants, well-being, and intervention. New York, NY: Routledge.

Butkovic, A., Hlupic, T. V., \& Bratko, D. (2017). Physical activity and personality: A behaviour genetic analysis. Psychology of Sport \& Exercise. Doi: 10.1016/j.psychsport.2017.02.005.

Coen, S. E., Rosenberg, M. W., \& Davidson, J. (2018). "It's gym, like g-y-m not J-i-m": Exploring the role of place in the gendering of physical activity. Social Science \& Medicine, 196, 2936.

Craig, C.L. Marshall, A.L. Sjostrom, M., et al. (2003) International physical activity questionnaire: 12-country reliability and validity. Medicine and science in sports and exercise, 35, 138195.

Duncan, L., Hall, C., Wilson, P., \& O, J. (2010). Exercise motivation: a cross-sectional analysis examining its relationships with frequency, intensity, and duration of exercise. International 
Journal of Behavioral Nutrition and Physical Activity, 7(1), 7. http://dx.doi.org/10.1186/1479-5868-7-7.

Feist, J., \& Feist, G. J. (2013). Theories of Personality: 8th Edition. New York, NY: McGraw Hill. Hakim, L. (2017). Penyakit utama penyebab kematian di Indonesia. Antaranews.com.

Ingledew, D., Markland, D., \& Sheppard, K. (2004). Personality and self-determination of exercise behaviour. Personality and Individual Differences, 36(8),1921-1932. http://dx.doi.org/10.1016/j.paid.2003.08.021

Ingledew, D. K., \& Markland, D. (2008). The role of motive in exercise participation. Psychology and Health, 23(7), 807-828.

Juliana, M. S. (2015). Hubungan aktivitas fisik dan kualitas tidur remaja. Skripsi Universitas Indonesia.

Kementrian Kesehatan Republik Indonesia. (2017, July 29). Penyakit jantung penyebab kematian tertinggi, Kemenkes ingatkan CERDIK.

Kern, M. L., Reynolds, C. A., \& Friedman, H. S. (2010). Predictors of physical activity patterns across adulthood: A growth curve analysis. Personality and Social Psychology Bulletin 36(8), 1058-1072.

Lochbaum, M. R., Rhodes, R. E., Stevenson, S. J., Surles, J., Stevens, T., \&Wang, C. K. J. (2010). Does gender moderate the exercising personality? An examination of continuous and stagebased exercise. Psychology, Health \& Medicine, 15(1), 50-60. DOI: 10.1080/13548500903443449

Macovei, S., Tufan, A. A., \& Vulpe, B. I. Theoretical approaches to building a healthy lifestyle through the practice of physical activities. Social and Behavioral Sciences, 117, 86-91.

Markland, D., \& Tobin, V. (2004). A modification to the behavioural regulation in exercise questionnaire to include an assessment of amotivation. Journal of Sport and Exercise Psychology, 26(2), 191-196. http://dx.doi.org/10.1123/jsep.26.2.191.

Ramsey, M., \& Hall, E. (2016). Autonomy mediates the relationship between personality and physical Activity: An application of self-determination theory. Sports, 4(2), 25. http://dx.doi.org/10.3390/sports4020025.

Rhodes, R. E., \& Smith, N. E. I. (2006). Personality correlates of physical activity: a review and meta-analysis. Br J Sports Med, 40, 958-965. Doi: 10.1136/bjsm.2006.028860.

Rhodes, R. E., \& Nigg, C. R. (2011). Advancing physical activity theory: A review and future direction. Exercise and Sport Sciences Reviews, 39(3), 113-119.

Ryan, R. M., \& Deci, E. L. (2017). Self-Determination Theory: Basic Psychology Needs in Motivation, Development, and Wellness. New York, NY: The Guilford Press.

Stephan, Y., Sutin, A. R., \& Terracciano, A. (2014). Physical activity and personality development across adulthood and old age: Evidence from two longitudinal studies. Journal of Research in Personality 49, 1-7.

Wilson, K. E., \& Dishman, R. K. (2015). Personality and physical activity: A systematic review and meta-analysis. Personality and Individual Differences 72, 230-242.

World Health Organization (2017). Physical Activity. Media Centre.

Widowati, U. (Mei, 14, 2017). 10 Penyakit paling mematikan di Indonesia. CNN Indonesia.

Wirawan, J. (July, 27, 2017). Kegemukan dan minimnya tingkat jalan kaki orang Indonesia. BBC Indonesia. 